\title{
Role of MAP kinases in sensory neurons on pain transmission
}

\author{
Koichi Noguchi \\ Department of Anatomy and Neuroscience, Hyogo College of Medicine
}

[Received 6 October 2005]

\begin{abstract}
Mitogen-activated protein kinases (MAPKs) are able to transduce extracellular stimuli into intracellular posttranslational and transcriptional responses in dorsal root ganglion (DRG). We have examined the phosphorylation of MAPKs, such as extracellular signal-regulated kinase (ERK) and p38, and found two kinds of responses of ERK and p38, in primary afferent neurons. One response involves rapid alteration of MAPKs, which noxious stimulation of the peripheral tissue induces in the DRG. We found that noxious stimulation of the peripheral tissue very rapidly induced phosphorylation of ERK and p38 in DRG neurons. Phosphorylation of MAPKs might be very useful as markers of primary afferent activation after noxious stimulation. Another response is the long-term changes in the DRG after a variety of types of neuropathic injury to the peripheral nerves. We found that chronic constriction injury (CCI) induced phosphorylation in ERK and p38 MAPK in different subpopulations of DRG neurons and also in satellite glial cells. L5 spinal nerve ligation (SNL) induced phosphorylation in p38 MAPK in neighboring L4 DRG neurons. We have also found that p38 inhibitors attenuated BDNF and TRPV1 expression increased in the L4 DRG and thermal hyperalgesia after L5 SNL. These data indicate that dynamic changes occur in uninjured primary afferent neurons, as well as injured neurons in neuropathic pain models, and might be important for the transmission of exaggerated pain (peripheral sensitization) in neuropathic pain conditions.
\end{abstract}

Key words: DRG; MAPK; ERK; p38; Neuropathic pain; Nociception; Gene expression

$$
\begin{gathered}
\text { 一次感覚ニューロンに拈ける MAP キナーゼと疼痛伝達 } \\
\text { 野口 光一 } \\
\text { 兵庫医科大学解剖学第 } 2 \text { 講座 }
\end{gathered}
$$

\begin{abstract}
緒言
MAP キナーゼをはじめとする細胞内情報伝達系 の活性化が，一次知覚ニューロンや脊髄後角ニュー ロンにおいて生じ, 痛みの発生やそれに伴う可塑的 な変化に重要な役割を担っていることがわかってき
\end{abstract}

た。これは蛋白質のリン酸化といった早期における 神経系の可塑的変化だけではなく, 遺伝子発現レベ ルでの制御といった long term な可塑的変化にも関 与している. 本稿では, 痛覚伝達における細胞内情 報伝達系の一つである MAP キナーゼの一次知覚 ニューロンに打ける動態, その疼痛伝達に打ける役 

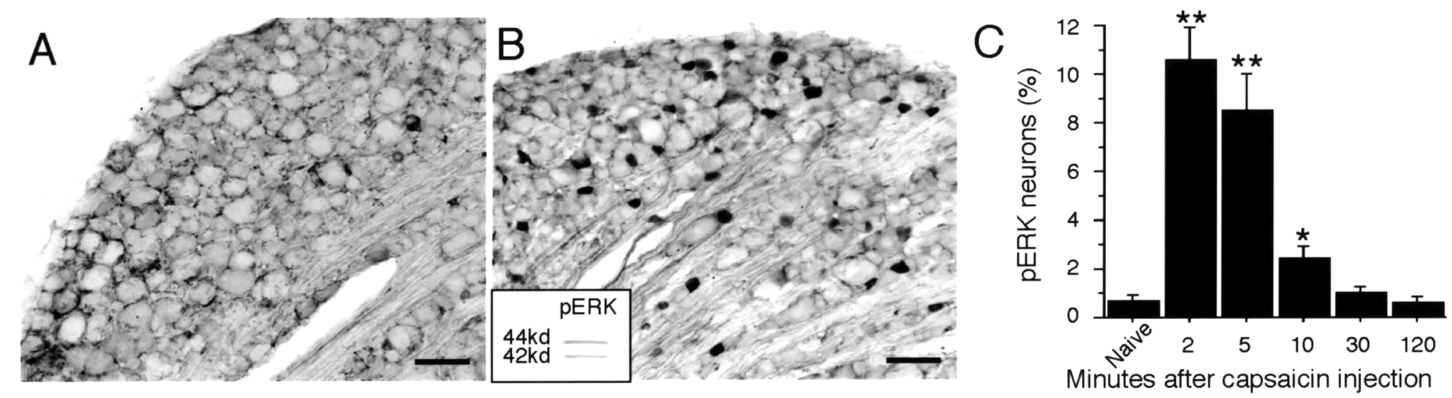

Fig. 1 Stimulus-evoked ERK phosphorylation in rat DRG neurons.

A. L4 DRG section $(30 \mu \mathrm{m})$ immunostained for pERK in the naive rat. B. pERK labeling in many small L4 DRG neurons 2 min after intraplantar injection of capsaicin (10 mM, $200 \mu \mathrm{l})$. Western blot of capsaicin-stimulated DRG tissue with pERK antibody (inset). C. Time course of capsaicin-evoked pERK expression in L4/5 DRG neurons $\left(n=5\right.$ each time point, ${ }^{*}: p<0.01,{ }^{* *}: p<0.001$ compared to naive). Scale bars, $100 \mu \mathrm{m}$. (From Dai et al., JN 2002)

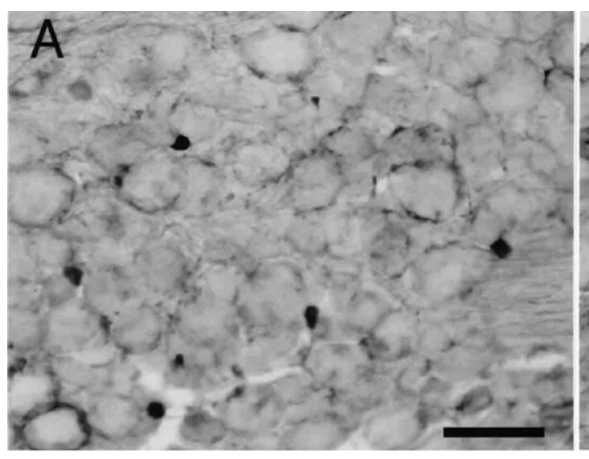

C

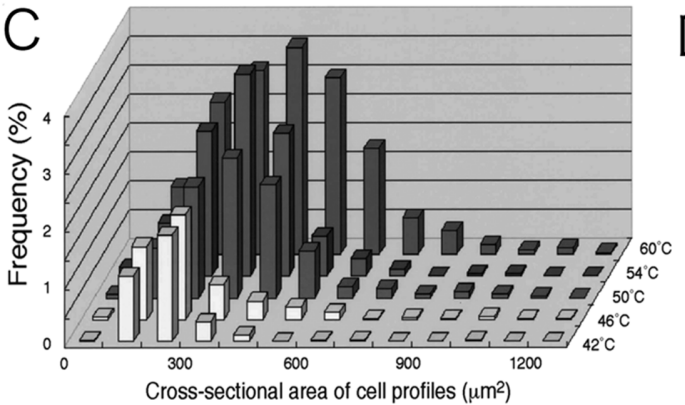

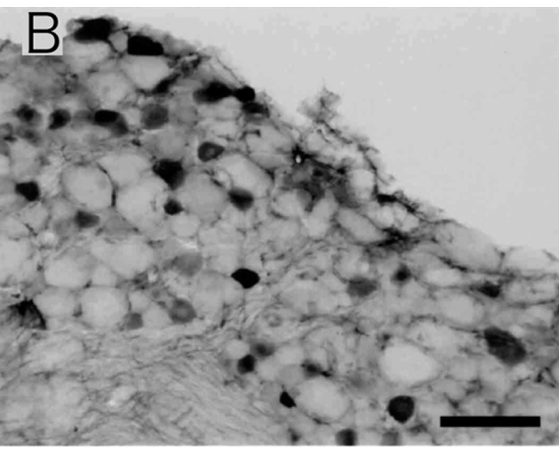

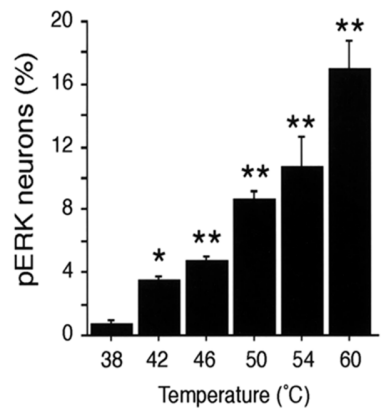

Fig. 2 Thermal stimulus intensity-dependent pERK expression.

A. pERK labeling in L4 DRG neurons 2 min after thermal stimulation at $42^{\circ} \mathrm{C}$. B. pERK labeling in L4 DRG neurons 2 min after thermal stimulation at $60^{\circ} \mathrm{C}$. C. Size distribution of $p E R K$-labeled neurons in the L4/5 DRGs 2 min after thermal stimulation at 42, 46, 50,54 , and $60^{\circ} \mathrm{C}$. D. The percentage of $\mathrm{pERK}$-labeled neurons in L4/5 DRG neurons $\left(\mathrm{n}=5\right.$ each temperature, ${ }^{*}: p<0.01,{ }^{* *}: p<0.001$ compared to $38^{\circ} \mathrm{C}$ ). Scale bars, $100 \mu \mathrm{m}$. (From Dai et al., JN 2002)

割について, 我々の知見を概説する.

\section{刺激様式に対応する DRG における ERK のリン酸化 ${ }^{1)}$}

カプサイシンを用いて，ラット末梢組織に存在す る無髄線維であるc-fiberを選択的に刺激すると， 後根神経節 DRGにおいて c-fiberを持つ小型
ニューロンにおいてのみ ERK のリン酸化が，刺激 後 2 分をピークとする非常に早い時間経過で誘導さ れる（Fig. 1A-C)。しかもこれらの pERK 陽性 ニューロンはカプサイシンの受容体である TRPV1 を含有していた。また A-fiber を選択的に刺激する と，有髄線維を持つ中型から大型の $\mathrm{DRG}$ ニューロ ンでの ERK リン酸化が観察された。カプサイシン 

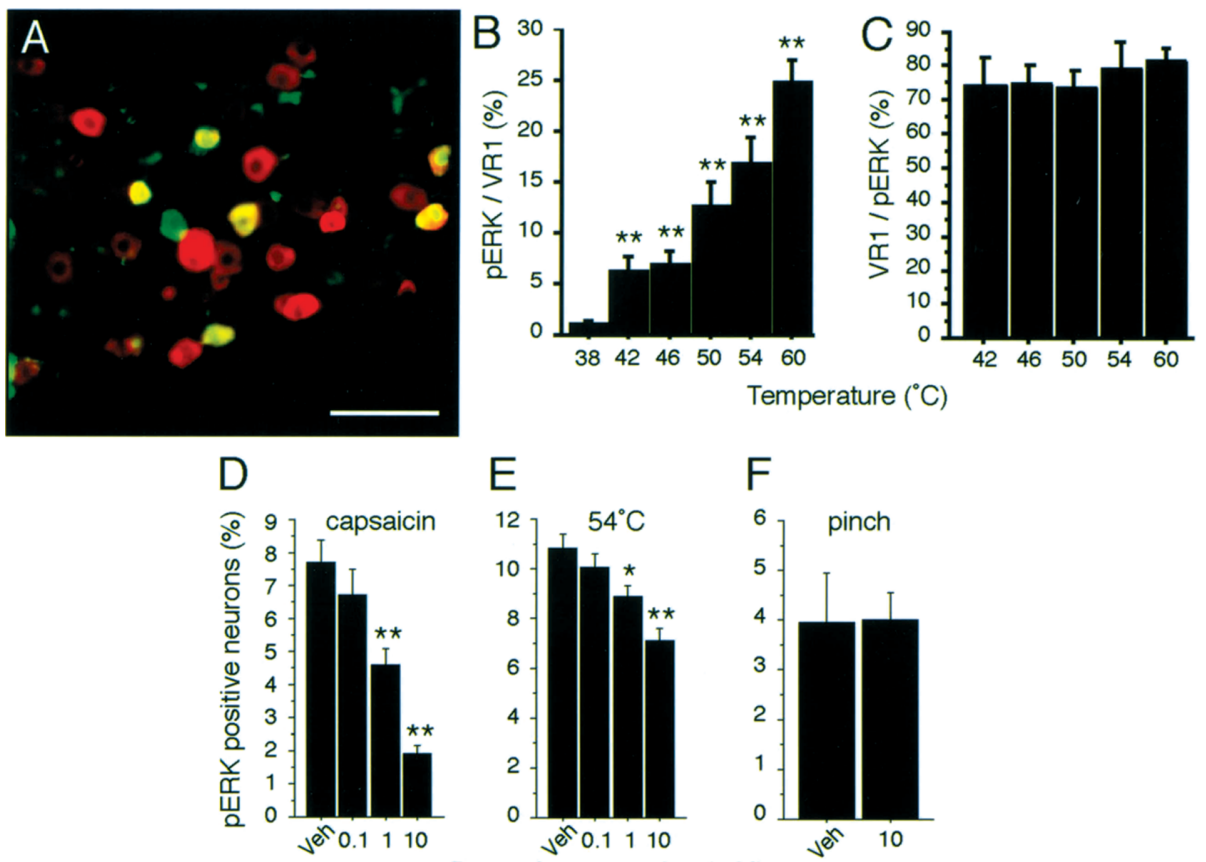

$\mathrm{E}$
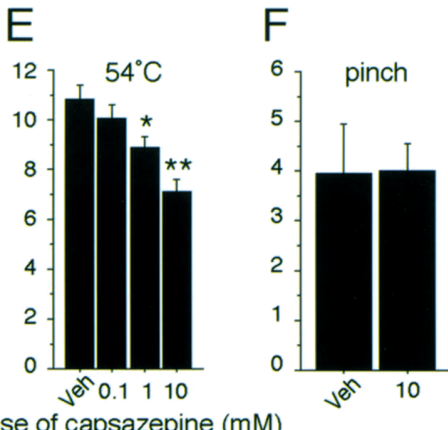

Dose of capsazepine $(\mathrm{mM})$

Fig. 3

A. Colocalization of pERK (green) and VR-1 (red) in L4 DRG neurons after thermal stimulation $\left(54^{\circ} \mathrm{C}\right.$ ) of the plantar surface of the hind paw. Double staining appears yellow. B. Percentages of VR-1-labeled neurons also labeled for pERK after different thermal stimuli ( ${ }^{* *}: p<0.001$ compared to $38^{\circ} \mathrm{C}$ ). C. Percentage of $p E R K$-labeled neurons also labeled for VR-1 after different thermal stimuli. D-F. Percentage of VR-1-labeled neurons in L4/5 DRG neurons following capsazepine treatment combined with capsaicin injection $(\mathrm{D})$, thermal stimulation $\left(54^{\circ} \mathrm{C}\right)(\mathrm{E})$ or mechanical stimulation of the plantar surface of the hind paw $(\mathrm{F})\left(^{*}: p<0.05,{ }^{* *}: p<0.001\right.$ compared to vehicle). Scale bars, $100 \mu \mathrm{m}$. (From Dai et al., JN 2002)
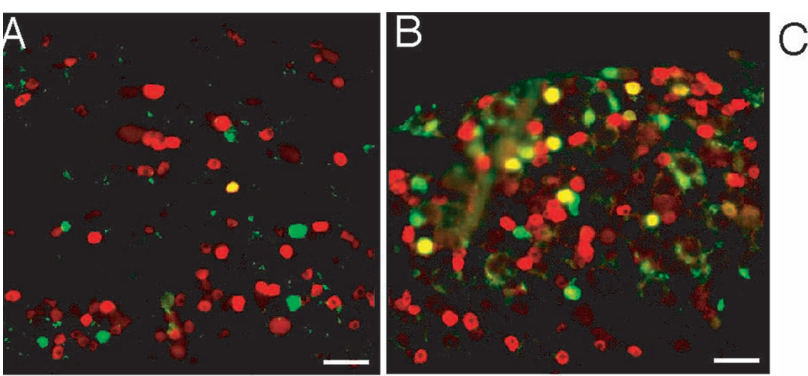

Fig. 4
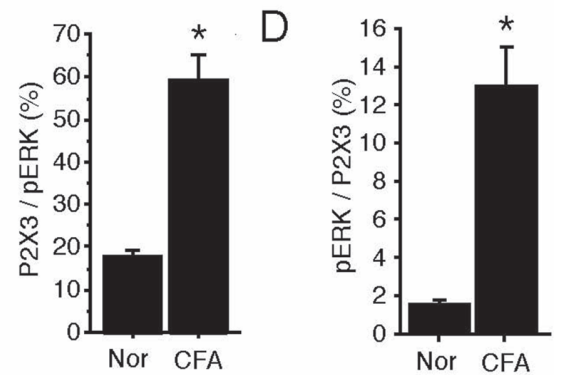

A, B: Co-localization of pERK (green) and P2X3 (red) in L5 DRG neurons of normal rats (A) or CFA rats (B) after mechanical noxious stimulation of the hind paw. Double staining appears yellow. C: Percentage of P2X3 immunoreactive neurons relative to pERKlabeled neurons in normal (Nor) rats and CFA-inflamed rats after mechanical stimulation. D: Percentage of pERK-labeled neurons relative to P2X3 immunoreactive neurons in normal (Nor) rats and CFA-inflamed rats after mechanical stimulation $\left(^{*}: p<0.01\right.$, Student's t-test). Scale bars, $100 \mu \mathrm{m}$. (From Dai et al., Pain 2004)

注射によって誘導される ERK のリン酸化は，Na チャンネルのブローカーである lidocaine の事前局 所投与によってブロックできることも明らかとなっ た。すなわち生体に侵害刺激が加わる際に，活動電 位の伝搬によって刺激様式特異的に，一次知覚神経
細胞において ERK カスケードが活性化されること が明らかとなった.

\section{刺激強度依存的な ERK 活性化 ${ }^{1)}$}

次に末梢組織に自然刺激を与えて, DRGにおけ 


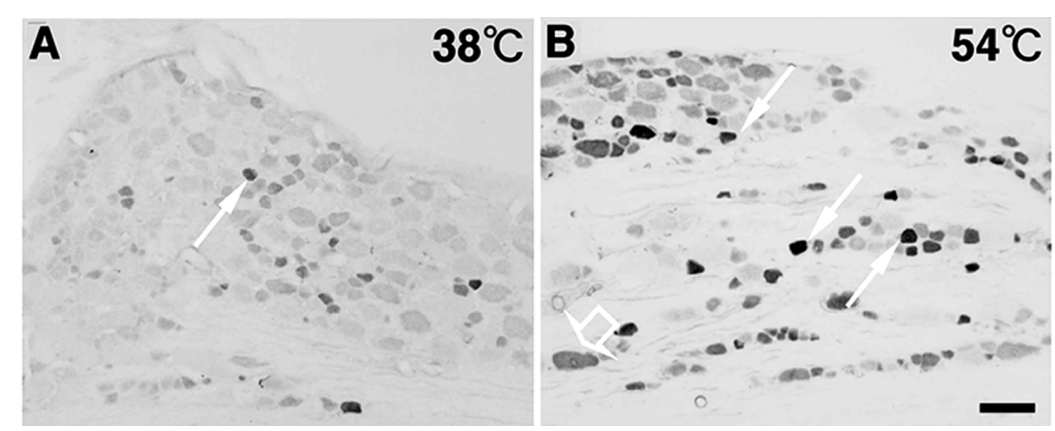

C

D
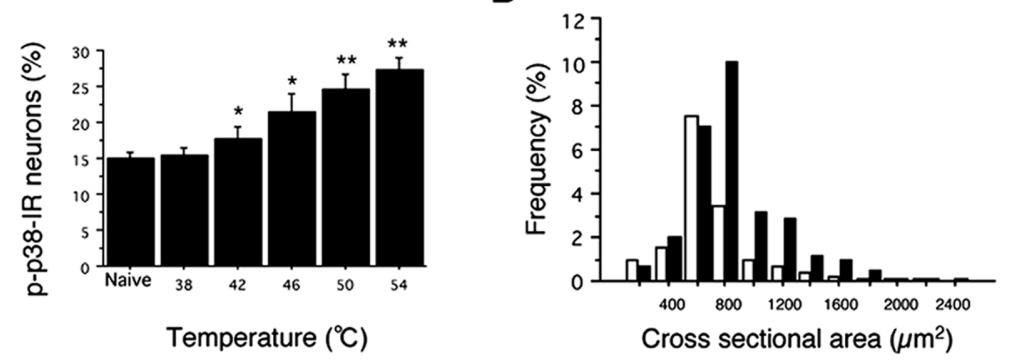

Fig. 5 Thermal stimulus intensity-dependent p-p38 expression.

L4 DRG section $(10 \mu \mathrm{m})$ immunostained for p-p38 2 min after thermal stimulation at $38^{\circ} \mathrm{C}(\mathrm{A})$ and $54^{\circ} \mathrm{C}(\mathrm{B})$. C. Quantification of the percentage of $p$-p38-IR neurons of L4/5 DRG neurons after thermal stimulation $\left({ }^{*}: p<0.05 ;{ }^{* *}: p<0.01\right.$ compared to naive). D. Size distribution of p-p38-labeled neurons in the L4/5 DRG 2 min after thermal stimulation at $54^{\circ} \mathrm{C}$ (black bars) and in the L4/5 DRG of naive rats (white bars). Scale bars, $100 \mu \mathrm{m}$. (From Mizushima et al., Pain 2005)

るERKのリン酸化を検索した. ERKの刺激強度を 変えると, 強度依存的に応答する (ERKリン酸化) 一次感覚細胞の population が変化することが明らか となった (Fig. 2A-D).つまり, 段階的に温度刺 激を与えると，より高い温度刺激で, ERKリン酸 化が起こる DRGニューロンの数が増加するだけで はなく，そのサイズが増大することがわかった。ま た電気刺激や機械刺激に扔いても同様の現象が観察 された。この結果は, 比較的にサイズの大きい (A $\delta$ 線維を持つ) ニューロンが, より強い刺激に応 答する可能性を示している.

\section{リン酸化 ERK は痛み関連受容体を同定する 有用なマーカー 1 )}

侵害性熱刺激によって誘導されるERKのリン酸 化が，TRPV1（VR1）の antagonistなどの事前局 所投与によってブロックできるかどうかを検討し た。まず，TRPV1 陽性ニューロン内での pERK 陽 性ニューロン（TRPV1 と pERKの二重標識細胞, Fig. 3A）の割合は, 温度に依存して増加すること
が明らかとなった (Fig. 3A-C)。ささに，熱刺激 に誘導されたリン酸化 ERK と TRPV1の二重染色 の割合は, TRPV1の antagonist の局所投与により 抑制でき，一方機械刺激によって誘導されたリン酸 化 ERKには何の影響も持たないことがわかった (Fig. 3D-F)。この結果は, カプサイシン刺激によ る一次知覚ニューロンに㧍ける ERKのリン酸化が, その受容体を介していることを示している.さらに この結果は, 拮抗䨩を用いた, 各種痛み関連受容体 とリン酸化 ERK の二重免疫染色法により, 疼痛刺 激様式と受容体の関連の分子組織化学的解析が可能 となったことを示唆している.

末梢組織炎症モデルにおいては, 一次知覚ニュー ロンの神経終末が末梢性感作を受け, 外部からの刺 激に対して明らかな過敏状態であることが知られて いる．炎症状態の神経終末の疼痛伝達にATPが重 要な役割を持っていることは既に多くの論文により 示唆されているが，今回我々はリン酸化 ERKを用 いてそれを検証した ${ }^{2)}$. 機械刺激による誘導される リン酸化 ERK と ATP 受容体 P2X3 との二重標識 

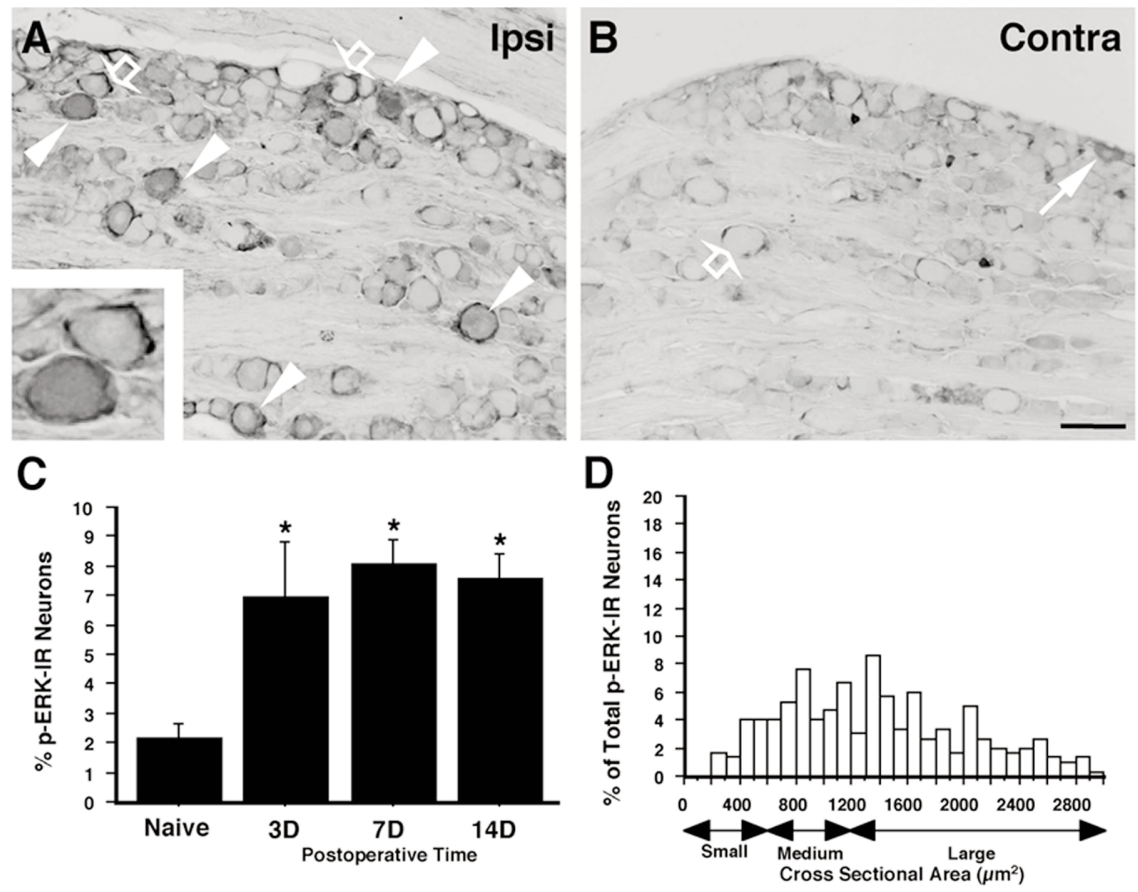

Fig. 6

A, B: Photomicrographs showing the p-ERK-IR in the ipsilateral (A) and contralateral (B) L4/5 DRG at 7 days after CCl surgery. The $\mathrm{CCl}$ increased $\mathrm{p}$-ERK expression in both neurons and surrounding satellite cells (arrowheads) or only in satellite cells surrounding large neurons (open arrows) in the ipsilateral DRG; the inset shows that both neurons and satellite cells expressed p-ERK-IR. C: Time course of the mean percentages of $p$-ERK-IR neurons relative to the total number of neurons in the DRG. ${ }^{*}: p<0.05$ compared to the naive control. D: Size-distribution histogram of $\mathrm{p}$-ERK-IR neuron profiles in the ipsilateral DRG at 7 days after $\mathrm{CCl}$ surgery. Scale bar: (in B) A, B, $100 \mu \mathrm{m}$. (From Obata et al., EJN 2004)

ニューロンは，正常状態では非常に少ないのに対し て，CFAによる炎症組織では多くの二重標識細胞 が観察された（Fig. 4A-D）。この結果は，正常組 織の機械的侵害受容に P $2 X 3$ 受容体はほとんど関与 しないが，炎症状態による疼痛過敏では大きな関与 を持っていることを示している.

\section{侵害熱刺激による p38MAPK のリン酸化}

ERK 以外の代表的 MAPK として, p38MAPK が 知られている。この p38に対するリン酸化抗体を用 いて, 侵害熱刺激をラット足底に与え, L4,5 DRG における p38のリン酸化を免疫組織化学法にて検出 した ${ }^{3)}$. その結果, リン酸化 p38 は, 正常状態にお いても $15 \%$ ほどの DRGニューロンにおいて存在 し，刺激温度が高くなるほど，特に侵害領域に入る と, 有意に多数のニューロンにおいて陽性細胞が観 察された（Fig. 5A-D）。 その変化の時間経過は, ERK の場合と同様に, 刺激後 2 分をピークとする,
非常に早い時間経過を示した。さらに ERKの場合 と同じく，侵害領域の高い温度により誘発されるリ ン酸化 p38 陽性ニューロン群は, サイズ分布が右方 向へ，つまりより大きなニューロン群で陽性反応が 観察されることが明らかとなった。 また，この p38 のリン酸化反応を拮抗剤で抑制すると, カプサイシ ン誘発熱性痛覚過敏が抑制できることが明らかと なった.つまり, p38のシグナル伝達機構の活性化 は, 一次知覚ニューロンの感作を通じて, 痛覚過敏 に直接関与していることがわかった。

\section{神経傷害モデル (CCI model) の DRG における MAPKs の活性化 ${ }^{4)}$}

疼痛行動の立進が観察される末梢神経傷害モデル が複数発表され，ニューロパチックペインモデルと してその行動薬理学的検索が広く行われている.さ らにその病態を精査することで, ニューロパチック ペインの病態に迫ろうとする多くの研究成果が報告 

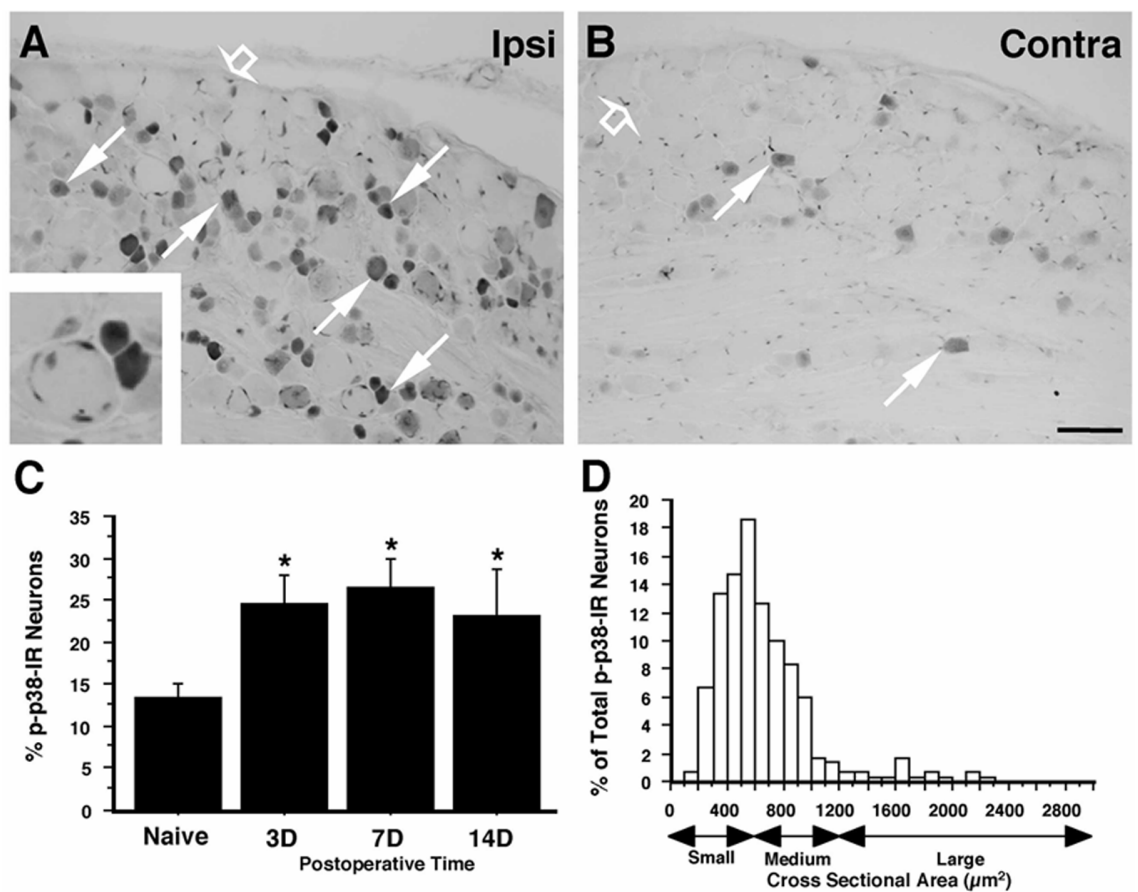

Fig. 7

A, B: Photomicrographs showing the p-p38-IR in the ipsilateral (A) and contralateral (B) L4/5 DRG at 7 days after $\mathrm{CCl}$ surgery. There was an increase in the number of p-p38-IR neurons (arrows) in the ipsilateral DRG. The number of p-p38-IR satellite cells was also greatly increased (open arrows); the inset shows that both neuron and satellite cell expressed p-p-38-IR. C: Time course of the mean percentages of $p$-p38-IR neurons relative to the total number of neurons in the DRG. ${ }^{*}: p<0.05$ compared to the naive control. D: Size-distribution histogram of p-p38-IR neuron profiles in the ipsilateral DRG at 7 days after CCI surgery. Scale bar: (in B) A, B, $100 \mu \mathrm{m}$. (From Obata et al., EJN 2004)

されてきた。我々もCCI モデルや後述の Chung モ デルなど, 部分神経損傷モデルの病態を検索してき たが，今回はモデルの DRGに㧍ける MAPKのリ ン酸化について検討した。 その結果， CCI モデル作 成後 1 週間後の DRG に抒いては, 中型から大型の ニューロンに抒いて ERKのリン酸化反応の増強が 観察された（Fig. 6A-D）次に我々が以前発表した 神経傷害マーカーとして有用な ATF3 との二重染色 を施行すると, 多くのリン酸化 ERK 陽性ニューロ ン $(82.6 \%)$ がATF3 を発現して打り, 多くの傷害 ニューロンにおいて ERKのリン酸化が充進してい ることがわかった。一方, p38MAPK についても検 討した（Fig. 7A-D）.CCI モデルの DRGにおい て, 劇的に増加したリン酸化 $\mathrm{p} 38$ が観察された。 ERK の場合と違って, 小型から中型のニューロン でその免疫反応の増加が観察された。また, ATF3 との二重染色ではごく一部のニューロン $(10.7 \%)$ で のみ共存が観察された。この結果は, ERKの場合
とは異なって，CCI モデルのような部分神経損傷に おいて, p38のリン酸化が生じるのは損傷から免れ た非損傷ニューロンであることが明らかとなった。

\section{神経傷害モデル (Chung model) における 遺伝子発現に対する MAPKs の役割 5)}

もう一つの代表的ニューロパチックペインモデル である Chung モデルは, L5 脊髄神経の結紮するこ とで, 疼痛過敏行動が生じるものである. 非損傷神 経である L4 脊髄神経を通じて, 未梢組織からの侵 害情報は脊髄ニューロンに伝達されるが, 我々はこ れまでこの非損傷ニューロンの集合体である L4 DRG に押いて, 多彩な遺伝子発現の変化が生じて いることを明らかにしてきた ${ }^{6 \sim 10)}$ 。今回は，この L5 脊䯣神経絞扼後の L4 DRG における MAPK の 変化を検討した．すぐ近傍の脊髄神経の切断を受け た L5 DRG に押いては，ERK および p38のリン酸 化反応は明らかに増加し，ニューロンおよび周囲の 


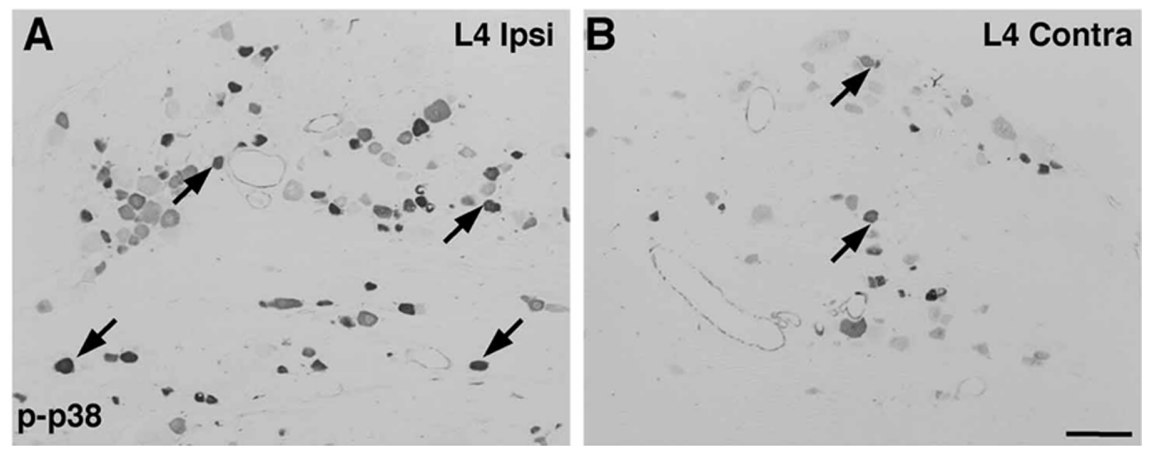

Fig. 8

A, B: Photomicrographs showing the p-p38-IR in the ipsilateral (A) and contralateral (B) L4 DRG at 7 days after L5 SNL surgery. There was an increase in the number of $p-p 38-I R$ neurons (arrows), but not satellite glial cells, in the ipsilateral L4 DRG. Scale bar: (in B) A, B, $100 \mu \mathrm{m}$. (From Obata et al., JN 2004)

衛星細胞において, 免疫反応の増大が観察された. 非損傷 DRG である L4 DRG に拈いても大きな変化 が観察され, 小型細胞から中型細胞のニューロンに おいて，多くのリン酸化 p38 陽性細胞が観察された (Fig. 8A, B). 興味深いことに，他の MAPKであ る ERKやJNK においてはL4 DRGにおける増加 は観察されなかった。これらのリン酸化 $\mathrm{p} 38$ 陽性 ニューロンは, TrkA と高い共存を示し, これらの 変化が神経成長因子（NGF）依存性であることを示 唆している.

さらにChung モデルの L4 DRGにおいて, BDNF (brain derived neurotrophic factor) や TRPV1の発 現が増加することも我々は報告している。リン酸化 p38 陽性ニューロンは，これらの BDNF や TRPV1 と高い共存率を示し, さらに 38 の拮抗剤を投与す ることで, L4 DRGにおける遺伝子発現の増加を抑 制することにも成功した。これらの結果は, 非損傷 ニューロンである L4 DRG において, p38 の活性化 が転写調節に関与し, 標的遺伝子である BDNFや TRPV1の発現調節に関わっていることを示してい る.さらにChung モデルに対して, p38 の拮抗剂 を投与すると侵害熱刺激に対する疼痛過敏反応が抑 制できることより, 上記の変化は疼痛行動に大きな 役割を持っていることが明らかとなった。

\section{最 後に}

我々の教室における一次感覚ニューロンにおける MAPKの役割に関する成果の一部を概説した。 MAPK が痛みの発生やそれに伴う可塑的な変化に
重要な役割を担っていることは明らかである ${ }^{11)}$. 今後，慢性痛に対する効果的な治療法の開発に向け て, 様々な動物モデルを用いた詳細な解析が必要と なってくるであろう。特異的なリン酸化阻害薬を用 いれば，リン酸化カスケードの任意のレベルで MAPK の活性化を阻害することが可能であり，痛 覚伝達に扔ける MAPK の役割は加速度的に解明さ れていくものと思われる.

\section{文献}

1) Dai, Y., Iwata, K., Fukuoka, T., Kondo, E., Tokunaga, A., Yamanaka, H., Tachibana, T., Liu, Y. and Noguchi, K., Phosphorylation of extracellular signal-regulated kinase in primary afferent neurons by noxious stimuli and its involvement in peripheral sensitization, J. Neurosci., 22 (2002) 7737-7745.

2) Dai, Y., Fukuoka, T., Wang, H., Yamanaka, H., Obata, K., Tokunaga A. and Noguchi, K., Contribution of sensitized P2X receptors in inflamed tissue to the mechanical hypersensitivity revealed by phosphorylated ERK in DRG neurons, Pain, 108 (2004) 258-266.

3) Mizushima, T., Obata, K., Yamanaka, H., Dai, Y., Fukuoka, T., Tokunaga, A., Mashimo, T. and Noguchi, K., Activation of p38 MAPK in primary afferent neurons by noxious stimulation and its involvement in the development of thermal hyperalgesia, Pain, 113 (2005) 51-60.

4) Obata, K., Yamanaka, H., Dai, Y., Mizushima, T., Fukuoka, T., Tokunaga, A. and Noguchi, K., Differential activation of MAPK in injured and uninjured DRG neurons following chronic constriction injury of the sciatic nerve in rats, Eur. J. Neurosci., 20 (2004) 2881-2895. 
5) Obata, K., Yamanaka, H., Kobayashi, K., Dai, Y., Mizushima, T., Katsura, H., Fukuoka, T., Tokunaga, A. and Noguchi, K., Role of the MAPK activation in injured and intact primary afferent neurons for mechanical and heat hypersensitivity after spinal nerve ligation, J. Neurosci., 24 (2004) 10211-10222.

6) Fukuoka, T., Kondo, E., Dai, Y., Hashimoto, N. and Noguchi, K., Brain-derived neurotrophic factor increases in the uninjured dorsal root ganglion neurons in selective spinal nerve ligation model, J. Neurosci., 21 (2001) 4891-4900.

7) Tsuzuki, K., Kondo, E., Fukuoka, T., Dai, Y., Tsujino, H., Sakagami, M. and Noguchi, K., Differential regulation of P2X3 mRNA expression by peripheral nerve injury in intact and injured neurons in the rat sensory ganglia, Pain, 91 (2001) 351-360.
8) Fukuoka, T., Tokunaga, A., Tachibana, T., Dai, Y., Yamanaka, H. and Noguchi, K., VR1, but not P2X3, increases in the spared L4 DRG in rats with L5 spinal nerve ligation, Pain, 99 (2002) 111-120.

9) Fukuoka, T. and Noguchi, K., Contribution of the spared primary afferent neurons to the pathomechanisms of neuropathic pain, Molecular Neurobiology, 26 (2002) 57-67.

10) Obata, K., Yamanaka, H., Fukuoka, T., Dai, Y., Tokunaga, A., Hashimoto, N., Yoshikawa, H. and Noguchi, K., Contribution of injured and uninjured DRG neurons to pain behavior and the changes in gene expression following chronic constriction injury of the sciatic nerve in rats, Pain, 101 (2003) 65-77.

11) Obata, K. and Noguchi, K., MAPK activation in nociceptive neurons and pain hypersensitivity, Life Sci., 74 (2004) 2643-2653.

Address for correspondence: Koichi Noguchi, M.D.

Department of Anatomy and Neuroscience, Hyogo College of Medicine

1-1 Mukogawa, Nishinomiya, Hyogo 663-8501, Japan

Tel: 0798-45-6415 